\title{
Analysis on Innovative and Entrepreneurial Education for College Students with Creative Space
}

\author{
Ni Minghui ${ }^{1,}$, , Ding bo ${ }^{2}$, Zhang liucheng ${ }^{3}$, Fan jihong ${ }^{4}$, Yuan yongjiu ${ }^{5}$ \\ 1, 3, 4, 5 Heilongjiang Institute of Technology China \\ ${ }^{2}$ Harbin University of Commerce China \\ *email:nmhfzk@sina.com
}

Keywords: Creative space; University; Innovation and Entrepreneurship; Education System

\begin{abstract}
Innovative and entrepreneurial education has become an inexorable trend which Chinese higher education reforms and develops. Universities provide innovative and entrepreneurial education platforms for college students through creative spaces. This article will summarize the problems of the education system of innovation and entrepreneurship based on Creative spaces; set up four educational models, propose the specific implementation of the education system of innovation and entrepreneurship for college students in the creative space.
\end{abstract}

In 2015, General Office of the State Council published Guidance on the Education Reform of Innovation and Entrepreneurship in Universities which sets a goal of developing the education system of innovation and entrepreneurship in universities. The creative space strategy advocated by our government will definitely promote the development of the innovation and entrepreneurship in a new situation.

\section{Creative Space Types and Creative Space in Universities}

Creative space integrates unused resource to achieve resource sharing and mutual benefit through providing companies the low-cost, convenient, fast, and open entrepreneurial service platform. It could be divided, by the organizer, into three types: the government type, the industry type, and the university type. The government type is invested and developed by the government, and presided by the local government departments, such as the Science and Technology Bureau and the Human Resources and Social Bureau. The industry type is upgraded from the original Internet companies, pioneer parks, and company incubators. The university type takes the universities as subject collaborating with industries and the government, and is managed and operated by the university or an outsourcing company. It can be divided into single function type and full function type. Single function type only provides a single link service for start-ups, such as the creative space of a university town. In addition to providing places for enterprises, the full-functional type also provides management consulting, training, assistance and other all-round services. According to the direction of industry, it can be divided into two types: professional and comprehensive. Professional type refers to the integration of similar entrepreneurial projects or start-up companies. Most of the enterprises in the public creative space are comprehensive type, and the projects and business of the enterprises are intersected.

The creative space in university, with the college and university background, is a united platform of social enterprises and the university enterprises which provides various services. As the main entrepreneurial force, college students are both energetic and enthusiastic. They can turn science and technology into productivity. In order to attract lots of enterprises to join in, the initial stage of social creative space will lower the entry threshold of enterprises, and even provide services such as venues for free. The business profit includes rent, service charges, value-added income in investment 
docking services, government subsidies obtained, and equity financing commissions for entrepreneurial projects, etc.

\section{The existing problems of the education system of innovation and entrepreneurship based on social creative spaces}

Innovation and entrepreneurship courses have become compulsory and minor courses in some universities of other countries and formed a complete curriculum system. At present, University innovation and entrepreneurship education is still in the process of exploration. First, we don't attach importance to it. Some university administrators believe that entrepreneurship education is only the enlightenment of innovative thinking and cannot be integrated into higher education. The success of college students' entrepreneurship is minority in fact. Entrepreneurship education only arouses students' innovation consciousness, and it is not combined with talent cultivation and quality education. Second, the work of the departments which are responsible for innovation and entrepreneurship education in colleges and universities is unclear. There is no indication of responsibilities among the employment department, the department of academic engineering, the entrepreneurship center, and the office of academic affairs, and the inconsistent management mechanism results in low efficiency. Third, it is imperfect supporting. The amount of entrepreneurial support funds allocated by the government has rarely been implemented in enterprises. Comparing with universities in developed countries, entrepreneurial funds, entrepreneurial venues and teachers are slightly insufficient. Fourth, the combination of the creative space and the university practice base is not close. Innovative entrepreneurship education only stays at the theoretical level, and it is still the beginning of application. For the sake of the interests, some universities tend to be profitable and ignore the importance of the creative space as a practice base.

\section{Construction of innovation and entrepreneurship for college students in creative space}

University education is guided by innovation. Government, creative space, and universities are linked together to promote the development of innovative and entrepreneurial education.

\subsection{The practical alliance model}

Based on the existing resources such as laboratories or engineering centers, the university contacts other creative spaces to form an entrepreneurial alliance, and establishes innovative training-type practical cooperation relationships with entrepreneurial enterprises. The alliance aims to sharing resource, getting information fast, and exchanging professionals and resource. First, the alliance can choose college students to the surrounding intended Creative spaces in batchs to complete the practical cooperation tasks. Students can exercise their practical ability through "doing” and increase their entrepreneurial pleasure and experience. Second, the alliance can introduce professionals and consultants to guide entrepreneurial practice and conduct regularly various discussions and lectures on cooperation between industry and university or research institutes. Third, the alliance can play the role of "holding the group to warm up", achieving centralized procurement, reducing costs, and improving efficiency.

\subsection{The government-industry-university collaboration model}

Government, university, entrepreneurship space, financial institutions and technology intermediaries play different roles in innovation and entrepreneurship education. The government, colleges and Creative spaces are the mainstay of innovation and entrepreneurship education, and the government gives entrepreneurship education support in terms of policies and funds.

When teaching students and enlightening their sense of innovation, universities should also provide students with software and hardware equipment support to ensure the unification of information flow, knowledge flow and capital flow. Creative space provides services, connects with banking institutions and venture capital institutions, and builds an entrepreneurial platform. 


\subsection{The research project implementation model}

The research projects include three forms: university teachers' own research and development projects; enterprise research projects; and scientific research institutions projects. The projects can be hatched in the Creative space and transformed into industry. In this model, as a project implementation base, Creative space can set up a mentor apprenticeship with universities to ensure that each project has "special person for guidance + student independent learning + innovation and entrepreneurship training + project industrialization”. For example, the "instructor-undergraduate talent incubation station” established by Huazhong University of Science and technology has incubated corporate research projects. Whether from student innovation training or from scientific research projects, it is extremely applicable.

\subsection{The alumni association and community model}

University sets up an alumni association. And the well-known alumni of various enterprises will provide entrepreneurial project resources for the Creative space. Universities organize alumni representatives with students regularly to discuss whether the project is feasible, to establish a practical experiencing entrepreneurial platform, and to promote project docking through entrepreneurial forums, entrepreneurial salons, and lectures, etc. The students who do not have training programs, can use the VBSE cross-professional comprehensive training platform to simulate the establishment of the company and the operation of the market. Students can engage in different positions in various social organizations to enhance the entrepreneurial experience.

With the creative space, the innovation and entrepreneurship education model of college students has the characteristics of diversity, comprehensiveness and continuity. All these four models depend on the support of government policies and funds, the research projects to ensure that everything go smoothly, the participation of the universities, and even the mentors' ability and network resources. Universities should establish actively the laboratory platforms, the simulation platforms, the enterprise docking platforms and student competition platforms to create innovative and entrepreneurial education with the innovation space. As shown in Figure 1.

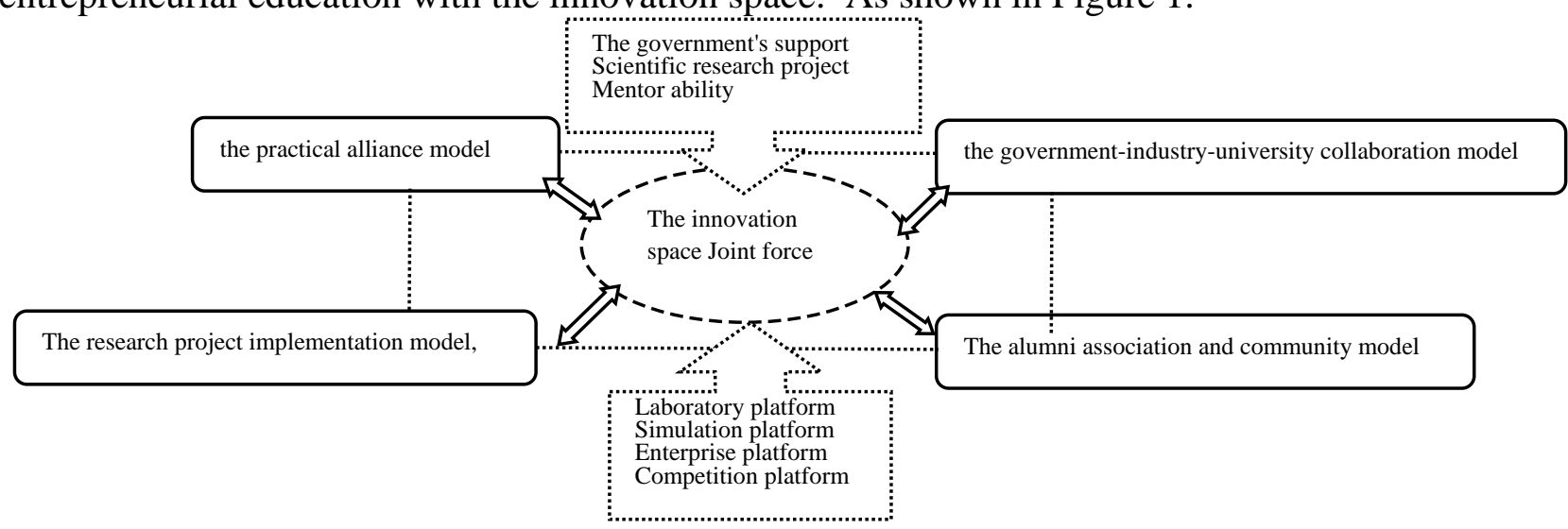

Fig. 1 The education model of innovation and entrepreneurship for college students with Creative space

\section{Realization of College Students' Innovation and Entrepreneurship Education by the Creative Space}

\subsection{Forming curriculum system that combines innovation and entrepreneurship education with Innovation space.}

Universities should establish a talent training system with entrepreneurship education as the starting point, and train students in different specialties. Relying on creative space, we will explore human resources, introduce enterprise professionals and entrepreneurial experts to teach and guide the practice of the base. In addition to the basic entrepreneurship courses in which all majors are set 
up in the curriculum, students should develop their entrepreneurial abilities according to different majors and choose courses related to entrepreneurship through their own interests. Especially in the student entrepreneurship competitions over the years, it was found that science and engineering students offered new and high-tech projects, but they were often not good at writing the business plan, which influenced the performance of the competition. If arts and sciences can be integrated, it will greatly help students in their future business. For example, science and engineering students can choose courses such as accounting foundation, business plan writing, communication management, etc. The diversification of the curriculum can increase students' interest in learning, so as to achieve the purpose of interest guidance.

\subsection{Setting up the system of education credit for innovation and entrepreneurship}

In addition to the innovative and entrepreneurial courses as a compulsory credit for general education, each college must also set up selective courses according to specific circumstances. Students must complete the credits for entrepreneurship education before graduation. Credits can be obtained through the following channels: (1) participating in the Innovative and Entrepreneurship Training Program for Undergraduates, and passing the acceptance test; (2)publishing the papers in the corresponding academic journals; (3) obtaining professional certificates for various professional qualifications; (4)obtaining patent certificates; (5)reporting student research projects; 6) participating in various discipline competitions; (7) starting a company; (8)other entrepreneurial activities.

\subsection{Clarifying the responsibility of innovation and entrepreneurship education and innovation space}

Universities should establish an institution to constrain entrepreneurial work, and to clarify the rights and responsibilities of the creative space, the university management department and the entrepreneurial enterprise. The university should set up a leading group for entrepreneurship education. The principal or vice president is the leader of the team, and a certain person in each department is appointed to be responsible for this job in order to create a situation in which all departments coordinating, planning and cooperation. For example, the person in charge of the industry department is responsible for the daily management of innovation space; the staff of the Academic Affairs Office is responsible for the related courses and credit management; the Ministry of Science and Engineering is responsible for the various competitions; The Finance Department is responsible for the management of the income and expenditure of the creation of the space; the Audit Office inspects and supervises the innovation space regularly. Teachers are encouraged to participate in Creative spaces. A mentoring mode and a studio mode should be established. Students are related to credits, while teachers are related to benefits. Thus teachers and students grow together.

\subsection{Increasing the investment of Creative spaces}

While receiving funds from the government, universities should strive for funds such as peripheral venture capital and angel investment, and increase the financial support for the mass entrepreneurship space enterprises. In addition to the funds for normal entrepreneurship funded by the government, universities can also raise funds through sponsorship or membership to set up a special fund for entrepreneurship which encourages college students to participate in entrepreneurial projects. Universities should contact well-known alumni and entrepreneurs actively in order to form alumni associations and participate in the guidance and training of the creative spaces. By opening the laboratory, the experimental demonstration center, the off-campus training base and other platforms, we create an open space for creative spaces, support innovation and entrepreneurship education from material resources, and give full play to the role of the practice base. 


\section{Acknowledgements}

Fund Projects: Research on the Mode of Innovation and Entrepreneurship Education for College Students from the Perspective of Public Creation Space, Key Project of Education and Teaching Reform of Heilongjiang Institute of Technology(JG2017007)

\section{References}

[1] Wang Liping, Li Zhonghua.The Development Model and Cultivation Path of College Doctor Culture[J].Jiangsu Higher Education， 2016(7):94-97

[2] Liu Guang, Yan Jinqiang, Discussion on the Practice of College Students' Innovation and Entrepreneurship Education Based on the innovation Space[J]. Experimental Technology and Management, 2016(12):30-35

[3] Wang Guohua. The concept and method of "Creative spaces" in the Internet age [J]. Journal of Beijing Union University (Humanities and Social Sciences Edition), 2016 (2).

[4] Song Shuqiang, Zhong Xiaoliu, Jiao Lizhen. Maker Education and Its Spatial Ecology Construction [J]. Modern Educational Technology, 2016, (1): 13-20.

[5] Wang Zhanren.Strategic Innovation to Promote Innovation and Entrepreneurship Education in Colleges and Universities [N]. Guangming Daily, 2016-02-04. 